\title{
Strategi Isi Pesan Kemasan dalam Mengomunikasikan Posisi Merek (Studi Mengenai Kemasan "Fruit Gum Blueberry" dari LOTTE)
}

\author{
Novida Irawan \\ Dosen Ilmu Komunikasi \\ Sekolah Tinggi Ilmu Komunikasi Profesi Indonesia
}

\begin{abstract}
ABSTRAK
Tujuan penelitian ini adalah untuk melakukan kajian secara deskriptif terhadap strategi isi pesan kemasan fruit gum Blueberry dari LOTTE dalam mengkomunikasikan posisi merek. Dengan menggunakan metode kualitatif yang bersifat deskriptif, jenis dan sumber datanya adalah data primer dan data sekunder. Untuk teknik pengumpulan datanya disesuaikan dengan fokus dan tujuan penelitian, yaitu menggunakan teknik observasi partisipatif dengan wawancara mendalam dan dokumentasi.

Diperoleh hasil bahwa elemen-elemen yang dimiliki kemasan Blueberry yang berkaitan dengan desain struktur kemasan seperti bentuk kemasan, ukuran kemasan dan material kemasan dan berkaitan dengan desain grafis kemasannya seperti warna, tipografi, logo, merek, dan ilustrasi merupakan strategi isi pesan kemasan yang menjadi penghantar pesan yang berkomunikasi langsung kepada konsumen. Jadi pesan kemasan tidak hanya berasal dari satu komponen saja, tetapi disampaikan dalam satu kesatuan dengan komponen yang lain.

Dari kesimpulan disarankan supaya LOTTE sebagai produsen fruit gum Blueberry supaya mempersiapkan rencana program kegiatan promosi dan periklanan terutama kemasannya lebih baik dan fleksibel yaitu tetap konsisten dalam mengomunikasikan positioning-nya. Sehingga dapat menjaga kekuatan merek Blueberry yang dapat fleksibel dalam mengomunikasikan positioning mereknya.
\end{abstract}

\section{PENDAHULUAN}

Dunia bisnis sangat kompetitif, berbagai tehnik dan strategi diperlukan untuk memenangkan persaingan dalam merebut pasar sebagai sarana menuju keberhasilan. Mendesain kemasan produk yang sesuai dengan permintaan pasar merupakan salah satu cara yang bisa diterapkan dalam persaingan itu. Sehingga, konsep pengemasan produk perlu mendapat perhatian, agar usaha untuk memenangkan persaingan. Kemasan bukan hanya sekedar pembungkus, tetapi juga memberikan gambaran tentang citra dan informasi produknya, serta adanya komunikasi antara konsumen dan produsen. Selain itu juga sebagai duta bagi produk itu sendiri.

PT. Lotte Indonesia merupakan salah satu produsen chewing gum, memasarkan produknya di tengah-tengah pasar chewing gum dengan berbagai merek atau brand. Perusahaan ini menciptakan tantangan bagi para desain produknya untuk mendesain kemasan yang bisa meningkatkan penjualan. Tantangan yang lain adalah PT. Lotte Indonesia tidak hanya mengharapkan peningkatan penjualan tetapi juga menjaga agar konsumennya tetap setia menggunakan produknya. Desain kemasan digunakan sebagai alat untuk mengkomunikasikan merek. Penelitian ini bertujuan untuk melakukan kajian secara deskriptif terhadap strategi isi pesan kemasan fruit gum Blueberry dari LOTTE dalam mengkomunikasikan posisi merek (Brand Positioning).

\section{Teori Komunikasi Pemasaran}


Ada tiga unsur pokok dalam struktur proses komunikasi pemasaran, yaitu ${ }^{1}$ :

1. Pelaku komunikasi, terdiri atas pengirim (sender) atau komunikator yang menyampaikan pesan dan penerima (receiver) atau komunikan pesan. Dalam konteks ini, komunikatornya adalah produsen/perusahaan, sedangkan komunikannya adalah khalayak, seperti pasar pribadi, pasar organisasi, maupun masyarakat umum (yang berperan sebagai initiator, influencer, decider, purchaser, dan user).

2. Material Komunikasi, ada beberapa material komunikasi pemasaran yang penting, yaitu: Gagasan, Pesan (message), Media, Response, Feedback, Ganguan (noise).

3. Proses Komunikasi, proses penyampaian pesan (dari pengirim kepada penerima) maupun pengirim kembali respon (dari penerima kepada pengirim) akan memerlukan dua kegiatan, yaitu encoding (fungsi mengirim) dan decoding (fungsi menerima).

Komunikasi pemasaran mempunyai tiga tujuan utama, yaitu untuk menyebarkan informasi (komunikasi informatif), mempengaruhi untuk melakukan pembelian atau menarik konsumen (komunikasi persuasif), dan mengingatkan khalayak untuk melakukan pembelian ulang (komunikasi mengingatkan kembali). ${ }^{2}$

Menurut Kotler, inti pemasaran strategis modern terdiri atas tiga langkah pokok yaitu Segmentasi, Penentuan Pasar Sasaran, dan Positioning. Ketiga langkah ini sering disebut STP (Segmenting, Targeting, Positioning) ${ }^{3}$.

a) Segmenting, Segmentasi pasar yakni mengidentifikasikan atau membentuk kelompok pembeli yang terpisah-pisah yang membutuhkan produk dan/atau bauran pemasaran tersendiri.

b) Targeting, Penentuan pasar sasaran, yakni memilih satu atau lebih segmen pasar untuk dimasuki/dilayani.

c) Positioning, positioning bukanlah strategi produk, tetapi strategi komunikasi. Ia berhubungan dengan bagaimana konsumen menempatkan produk di dalam otaknya, di dalam alam khayalnya, sehingga calon konsumen memiliki penilaian tertentu dan mengidentifikasikan dirinya dengan produk/merek itu. Konsumen yang di maksud adalah konsumen yang menjadi targetnya. ${ }^{4}$

\section{Teori Strategi Pemasaran}

Pada dasarnya strategi pemasaran memberikan arah dalam kaitannya dengan variabel-variabel seperti segmentasi pasar, identifikasi pasar sasaran, positioning, elemen bauran pemasaran, dan biaya bauran pemasaran. Strategi pemasaran merupakan bagian integral dari strategi bisnis yang memberikan arah pada semua fungsi manajemen suatu organisasi. $^{5}$

\section{Kemasan}

Kemasan (packaging) merupakan proses yang berkaitan dengan perancangan dan pembuatan wadah (container) atau pembungkus (wrapper) untuk suatu produk. ${ }^{6} \mathrm{Di}$ tengah persaingan yang semakin kompetitif, beberapa kalangan baik produsen maupun

\footnotetext{
${ }^{1}$ Fandy Tjiptono, Strategi Pemasaran. Edisi II. Yogyakarta: Andi. 1997 hal 219-220

${ }^{2}$ Fandy Tjiptono, Strategi Pemasaran. Edisi II. Yogyakarta: Andi. 1997 hal 220

${ }^{3}$ Ibid hal 69

${ }^{4}$ Rhenald Khasali, 1998, "Membidik Pasar Indonesia; Segmenting, Targeting dan positioning", Jakarta: PT. Gramedia Pustaka Utama. Hal 507

${ }_{6}^{5}$ Fandy Tjiptono, Strategi Pemasaran. Edisi II. Yogyakarta: Andi. 1997 hal 6

${ }^{6}$ Ibid hal 106
} 
pengamat pemasaran dan periklanan menganggap berpromosi lewat media cetak, media elektronik ataupun media luar ruang masih belum mencukupi untuk mempengaruhi konsumen. ${ }^{7}$ Salah satu cara yang saat ini dijadikan alternatif oleh produsen yaitu berpromosi lewat kemasan.

Penggunaan kemasan mempunyai tujuan: ${ }^{8}$ Sebagai pelindung isi (protection), untuk memberikan kemudahan dalam penggunaan (operating), bermanfaat dalam pemakaian ulang (reusable), memberikan daya tarik (promotion), sebagai identitas (image) produk, distribusi (shipping), informasi (labelling), sebagai cermin inovasi produk, berkaitan dengan kemajuan teknologi.

\section{Mendesain Kemasan}

Karena desain kemasan begitu penting bagi kesuksesan merek, diperlukan suatu pendekatan yang sistematis.

1. Menentukan Tujuan Pemosisian Merek.

Tahap pertama proses desain kemasan ini mengharuskan tim manajemen merek untuk menspesifikasi positioning merek tersebut dalam benak konsumen dan dalam persaingan, dengan berbagai merek kompetitif. ldentitas atau citra apa yang diinginkan bagi merek.

2. Melakukan Analisis Kategori Produk.

Setelah menentukan apa yang diwakili merek tersebut dan sekaligus apa yang harus diangkat oleh kemasan, penting bagi produsen kemasan untuk mempelajari kategori produk serta berbagai kategori lainnya yang berhubungan, guna menentukan tren-tren yang relevan atau mengantisipasi peristiwa-peristiwa yang akan mempengaruhi keputusan pengemasan.

3. Melakukan Analisis Kompetitif.

Dengan dibekali pengetahuan tentang penggunaan warna, bentuk, fitur tampilan, serta material kemasan milik kompetitor, desainer kemasan akan disiapkan untuk menciptakan kemasan yang mengangkat citra yang diinginkan namun juga cukup unik dan berbeda hingga mampu menangkap perhatian konsumen.

4. Mengidentifikasikan Atribut/Manfaat Merek yang Menonjol.

Seperti ditekankan sebelumnya, riset telah mengungkapkan bahwa orang-orang yang berbelanja menghabiskan waktu yang teramat sangat singkat untuk memandangi merek-merek sebelum bergerak memilih item dan menempatkannya dalam kereta belanja. Karenanya penting sekali agar kemasan tidak terlalu dijejali dengan informasi dan mengilustrasikan manfaat-manfaat yang terpenting bagi konsumen.

5. Menentukan Prioritas Komunikasi.

Setelah menyebutkan sebagian besar manfaat-manfaat Merek yang menonjol, proses ini secara sederhana mendorong desainer kemasan untuk menentukan prioritas verbal dan visual bagi kemasan. Meskipun mungkin tiga manfaatya telah diidentifikasi dalam tahap empat yang secara esensi seimbang kepentingannya, desainer harus memprioritaskan mana dari tiga manfaat tersebut yang mampu menangkap perhatian terbesar atas kemasan. ${ }^{9}$

\section{Desain Kemasan Sebagai Alat Komunikasi}

\footnotetext{
${ }^{7}$ AMR, 2001, “Gerilya Promosi Lewat Kemasan”, Cakram Komunikasi, Jakarta. Hal 9

${ }^{8}$ Fandy Tjiptono, loc cit hal 106

9 Terence A Shimp, 2003, “Periklanan dan Promosi”, Jakarta: Erlangga. Hal 319
} 
Desain kemasan adalah bisnis kreatif yang mengkaitkan bentuk, struktur, material, warna, citra, tipografi dan elemen-elemen desain dengan informasi produk agar dapat dipasarkan. ${ }^{10}$

Desain Kemasan Sebagai Alat Identifikasi dalam Pemasaran.

Desain kemasan berfungsi untuk mengkomunikasikan perbedaan produk secara visual. ${ }^{11}$ Dari sudut pandang penampilan, tanpa desain kemasan yang berbeda untuk semua merek produk, masing-masing produk akan terlihat sama.

\section{Desain Kemasan dan Merek}

Dari perspektif desain kemasan, merek adalah sebuah nama, sebuah tanda khas kepemilikan dan representasi produk, jasa, orang, dan tempat. ${ }^{12}$ Sebuah merek atau produk diproyeksikan pada suatu citra (image) tertentu (melalui periklanan). Gagasannya adalah konsumen dapat menikmati keuntungan psikologis dari sebuah produk (selain keuntungan fisik yang mungkin ada). Ini biasanya berorientasi pada simbol kehidupan. Pendekatan ini di populerkan oleh David Ogilvy dalam bukunya "Confessions of an Advertising Man". ${ }^{13}$

Branding atau permerekan bukan hanya merupakan penempatan simbol atau nama pada sebuah produk untuk dapat diidentifikasikan. Tapi merek adalah satu set atribut yang memiliki makna, citra dan menghasilkan asosiasi dengan suatu produk tertentu.

Brand image berarti merek yang bukan hanya dibedakan secara karakteristik fisik, tetapi merek dibentuk oleh citra merek yang berada di benak masyarakat, apa yang dipikirkan, dan divisualisasikan ketika konsumen melihat simbol dari merek tersebut.

\section{Prinsip-Prinsip Desain Kemasan}

Panduan ini membantu mendefinisikan bagaimana warna, tipografi, struktur dan citra diaplikasikan dalam suatu tata letak desain untuk menciptakan kesan keseimbangan, intensitas proporsi, dan penampilan yang tepat. Inilah yang membuat elemen-elemen desain membentuk atribut komunikatif suatu desain kemasan. ${ }^{14}$

\section{Berkomunikasi dengan Warna (Color)}

Warna adalah salah satu aspek yang paling berpengaruh dari desain kemasan. ${ }^{15}$ Warna merupakan perangsang paling penting yang menciptakan daya tarik visual dan daya tarik pada pelanggan dan ini merupakan bagian yang sangat penting dari desain grafis pada sebuah kemasan.

\section{Tipografi}

Huruf memiliki perpaduan nilai fungsional dan nilai estetik. Pengetahuan mengenai huruf dapat dipelajari dalam sebuah disiplin seni yang disebut tipografi. ${ }^{16}$ Tipografi juga memberi halaman sebuah kepribadian tertentu (formal atau informal,

\footnotetext{
${ }^{10}$ Marianne Rosner Klimchuk \& Sandra A. Krasovec, 2007, "Desain Kemasan: Perencanaan Merek Produk yang Berhasil Mulai dari Konsep sampai Penjualan”, Jakarta: Erlangga, Hal 33

${ }^{11}$ Ibid, hal 35

${ }^{12}$ Ibid, hal 38

${ }^{13}$ M. Suyanto, 2004, "Desain Grafis Dalam Periklanan", Yogyakarta: CV. Andi, Hal 117

${ }^{14}$ Marianne Rosner Klimchuk \& Sandra A. Krasovec, 2007, "Desain Kemasan: Perencanaan

Merek Produk yang Berhasil Mulai dari Konsep sampai Penjualan”, Jakarta: Erlangga, hal 82

${ }^{15}$ Ibid hal 107

${ }^{16}$ Danton Sihombing. 2001, “Tipografi Dalam Desain Grafis”, Jakarta: Gramedia Pustaka Utama, hal 2
} 
modern atau klasik, ramai atau tenang). Dan feeling keseluruhan (padat atau terbuka, ringan atau dramatis). ${ }^{17}$

\section{Struktur Dalam Desain Kemasan}

Dalam pikiran konsumen, kemasan adalah produk. Struktur dan material digunakan sebagai tempat penyimpanan, perlindungan dan trasportasi produk dan menyediakan permukaan fisik bagi desain kemasan.

\section{Berkomunikasi dengan Citra}

Persepsi mengenai suatu citra berbeda dari satu kebudayaan dengan kebudayaan lainnya. Bila digunakan secara efektif dalam desain kemasan, citra baik berupa ilustrasi maupun foto, dapat memberikan impresi visual yang kuat. Citra harus tepat dan langsung mengenai sasaran dalam mengkomunikasikan kepribadian merek dan atribut produk tertentu ${ }^{19}$.

\section{METODE PENELITIAN}

\section{Jenis dan Sifat Penelitian}

Jenis penelitian yang dilakukan adalah penelitian dengan menggunakan metode yang bersifat kualitatif dimana menurut Bagdan dan Taylor, penelitian kualitatif adalah penelitian yang menghasilkan data deskriptif berupa kata-kata tertulis tertulis atau lisan dengan orang atau perilaku yang diamati. ${ }^{20}$

Penelitian ini bersifat deskriptif, dimana penelitian memaparkan sebuah situasi atau peristiwa. Penelitian deskriptif artinya mencatat secara teliti segala gejala (fenomena) yang dilihat dan didengar serta dibacanya (via wawancara atau bukan, catatan lapangan, foto, video tape, dokumen pribadi, catatan atau memo, dokumentasi atau bukan, dan lain-lain). ${ }^{21}$

\section{Jenis dan Sumber Data}

a. Data primer, dalam melakukan pengumpulan data, penulis mengunakan tehnik cara atau metode yang dilakukan oleh peneliti dan disesuaikan dengan jenis penelitian kualitatif yaitu menggabungkan teknik observasi partisipatif dengan wawancara mendalam dan dokumentasi. ${ }^{22}$

b. Data sekunder, adalah data tambahan sebagai pendukung penelitian yang di peroleh penulis yaitu berupa pengumpulan data dengan mengkaji sumber-sumber kepustakaan, baik berbentuk buku, artikel atau jurnal-jurnal dan product knowledge fruit gum Blueberry, perpustakaan LOTTE dan artikel pendukung lainnya dari internet, yaitu: Berita Pengemasan, alamatnya http://packindo.org.

\section{Teknik Pengumpulan Data}

Dalam memperoleh data yang dibutuhkan sebagai bahan pembuatan laporan penelitian ini, ada beberapa tehnik, cara atau metode yang dilakukan oleh peneliti dan disesuaikan dengan jenis penelitian kualitatif yaitu menggabungkan teknik observasi partisipatif dengan wawancara mendalam dan dokumentasi. ${ }^{23}$ Selama melakukan observasi, peneliti juga melakukan interview kepada orang-orang yang ada di dalamnya.

\footnotetext{
${ }^{17}$ Sushan, Ronnie \& Don, Wright. 1991, "Desktop Publishing Dalam Desain”, Jakarta: PT. Elek Media Komputindo, Hal 14

${ }^{18}$ Marianne Rosner Klimchuk \& Sandra A. Krasovec, 2007, "Desain Kemasan: Perencanaan

Merek Produk yang Berhasil Mulai dari Konsep sampai Penjualan”, Jakarta: Erlangga, hal 137

${ }^{19}$ Ibid hal 120

${ }^{20}$ Lexy J. Moleong, 1999, "Metode Penelitian Kualitatif”, Bandung: Remaja Rosdakarya. Hal 3

${ }^{21}$ Burhan Bungin, 2003, "Metode Penelitian Kualitatif", Jakarta: Raja Grafindo Persada,. Hal 56

${ }^{22}$ Ibid Hal 63

${ }^{23}$ Ibid
} 
a) Observasi, dalam observasi partisipatif, peneliti mengamati apa yang dikerjakan orang, mendengarkan apa yang mereka ucapkan, dan berpatisipasi dalam aktifitas mereka. ${ }^{24}$ Dalam hal ini, peneliti melakukan observasi tentang pembuatan desain kemasan fruit gum Blueberry mengenai strategi komunikasinya di divisi creative and design PT. LOTTE INDONESIA.

b) Wawancara, adalah merupakan pertemuan dua orang untuk bertukar informasi dan ide melalui tanya jawab, sehingga dapat dikonstruksikan makna dalam suatu topik tertentu. ${ }^{25}$

Melakukan wawancara kepada Bapak Imam, Creative and Design Manager untuk mendapatkan data tentang strategi dalam merancang desain kemasan fruit gum Blueberry. Melakukan wawancara kepada Bapak Jusuf, Packaging Designer untuk mendapatkan data tentang proses perancangan desain kemasan yaitu prinsip-prinsip desain kemasan dan strateginya dalam mengkomunikasikan fruit gum Blueberry. Melakukan wawancara kepada Ibu Angel, Brand Supervisor untuk mendapatkan data tentang strategi dalam pembuatan konsep produk fruit gum Blueberry beserta promosinya.

c) Dokumen, merupakan catatan peristiwa yang sudah berlalu. Dokumen bisa berbentuk tulisan, gambar, atau karya-karya monumental dari seseorang. ${ }^{26}$ Dokumen yang berbentuk gambar misalnya, foto, gambar hidup, sketsa dan lainlain. Disini data dokumentasinya yaitu gambar kemasan produk fruit gum Blueberry.

\section{Tehnik Analisa Data}

Teknis analisi data yang digunakan dalam penelitian ini adalah analisi data kualitatif, mengikuti konsep yang diberikan Miles and Huberman (1984) yaitu data collection (Pengumpulan Data), data reduction (Reduksi Data), data display (Penyajian Data) dan conclusion drawing/verification (Penarikan Kesimpulan). ${ }^{27}$

\section{Tempat Penelitian}

Objek penelitian ini adalah desain kemasan fruit gum Blueberry produksi PT. LOTTE INDONESIA. Tempat penelitian dilakukan di bagian marketing Kantor cabang PT. LOTTE INDONESIA berlokasi di Jakarta, Jl. Ahmad Yani no. 78 (Kav. 15 - 16) Jakarta Pusat 10510.

\section{HASIL DAN PEMBAHASAN}

Analisis Produk dan Komunikasi Pemasaran Fruit Gum Blueberry

Fruit gum Blueberry merupakan salah satu rangkaian produk chewing gum dari LOTTE. Sebagai produk yang ditujukan untuk pasar global, seluruh pendekatan yang dilakukan terhadap fruit gum Blueberry merupakan pendekatan kelas A dan $\mathrm{B}+$. Produk chewing gum ini diberi nama fruit gum Blueberry untuk membedakannya dengan chewing gum yang lain. Produk ini dikemas dalam kemasan pack dengan berat bersih 15 g berjumlah 5 stick gum.

Menurut Angel, Brand Supervisor yang menangani proyek fruit gum Bluebery ini, "mempunyai profil target market sebagai berikut: Umur 19 - 25 Tahun, Jenis Kelamin wanita, Status Sosial Ekonomi A, B+, Geografis Perkotaan dan Psikografis Aktif, mempunyai tingkat kemapanan secara ekonomi dan sosial yang baik, mempunyai gaya hidup yang sangat memperhatikan aktifitas".

\footnotetext{
${ }^{24}$ Ibid hal 65

${ }^{25}$ Sugiyono, 2005, "Memahami Penelitian Kualitatif", Bandung: CV. Alfabeta, hal 72

${ }^{26}$ Ibid $82-83$

${ }^{27}$ Op Cit Hal 91
} 
Fruit gum Blueberry diluncurkan ke pasaran dengan wanita konsumen sebagai konsumen sasarannya. Nilai lebih (keunggulan produk) yang ditawarkan oleh produk fruit gum Blueberry ini adalah rasanya yang memang benar rasa buah asli dan juga sangat juicy. Seperti yang ditunjukkan oleh teks wawancara berikut ini: "Jadi untuk Uniqe Selling Pointnya pun sama dengan fruit gum yang lainnya yaitu...ee...apa ya...rasanya yang benar-benar seperti rasa buah asli dan juga sangat juicy. Jadi kalau misalnya dilihat...kalau misalnya kita ngerasain itu rasanya memang benar-benar seperti rasa Blueberry asli dan kita menonjolkan ke juici-an dari buah blueberry tersebut ke dalam chewing gum. Makanya kenapa kita menggunakan tagline kita yaitu: Kunyah Rasa Asli Buahnya."

Profil target market tersebut adalah landasan PT. LOTTE INDONESIA dalam menciptakan strategi pemasaran yang tepat bagi fruit gum Blueberry. Sehingga di dalam mendesain kemasan, gambar buah blueberry ini yang lebih ditonjolkan. Maksudnya adalah merek dari kemasan itu adalah blueberry dan ketika konsumen melihat kemasan tersebut akan mengerti bahwa permen tersebut memang rasa Blueberry. Seperti yang ditunjukkan oleh hasil wawancara berikut ini: "karena disini brand-nya pun Blueberry. Jadi dengan menampilkan gambar Blueberry nya itu orang-orang bisa melihat, oh...iya ... memang itu rasanya Blueberry."

Strategi pemasaran yang terpenting adalah menciptakan personality dan positioning merek. Dimana personality dan positioning merek ini akan membuat fruit gum Blueberry mempunyai awareness tersendiri dalam benak calon konsumen. Untuk menciptakan asosiasi tertentu yang dapat menciptakan brand image bagi fruit gum Bluebery dalam benak konsumen diantara para kompetitor yang ada.

Menurut Angel, Brand Supervisor Product fruit gum Bluebery, brand personality yang dimiliki fruit gum Blueberry adalah bahwa fruit gum Blueberry merupakan produk yang diproduksi secara eksklusif untuk wanita yang aktif yang punya style tersendiri, lively, stylish kemudian juga modern. Sehingga dalam distribusi dan pemasaran produk ini hanya bisa didapatkan di supermarket atau retail eksklusif yang mempunyai pelanggan sesuai dengan target marketnya. Seperti Carefour, Hypermart, Hero dan lain-lain.

Selain itu personality merek yang dimiliki fruit gum Blueberry adalah bahwa produk yang memiliki value, yaitu: Functional Value, yaitu bahwa fruit gum Blueberry adalah produk chewing gum yang mempunyai kandungan rasa buah asli yang segar dan baik untuk kesehatan. Emotional Value, yaitu bahwa fruit gum Blueberry adalah produk chewing gum yang menawarkan keeksklusifan dan sophisticated desain yang tidak dimiliki langsung oleh kompetitor. Esthetic Value, yaitu bahwa fruit gum Blueberry menawarkan suatu nilai gaya hidup tersendiri yang aktif, stylish dan modern yang sangat memperhatikan estetika. Menjadi nilai tambah bagi calon konsumen di dalam merasakan benefit yang dimiliki oleh fruit gum Blueberry. Dari personality yang dimiliki oleh fruit gum Blueberry tersebut, maka diciptakanlah suatu positioning yang dikomunikasikan oleh fruit gum Blueberry dalam setiap kegiatan komunikasi pemasarannya, baik itu kegiatan promosi atau yang lainnya. Positioning yang dimiliki fruit gum Blueberry adalah memposisikan wanita yang adult yang aktif, stylish dan modern. Dan mempunyai arti produk fruit gum Blueberry adalah sebuah fruit gum yang rasa buah asli, eksklusif dan diciptakan untuk sebuah gaya hidup yang aktif dan modern.

Kemudian positioning tersebut digunakan oleh PT. LOTTE INDONESIA dalam menyusun strategi komunikasi pemasaran fruit gum Blueberry dan menerapkannya dalam setiap kegiatan komunikasi pemasaran yang dilakukan. Dimulai dengan mengkomunikasikan positioning tersebut melalui kemasan produknya, seperti telah diketahui bahwa kemasan adalah komponen terpenting dari suatu produk yang digunakan 
sebagai alat komunikasi yang patut diperhitungkan karena yang pertama kali dilihat sebelum kenal merek adalah kemasan.

\section{Mendesain Kemasan Fruit Gum Blueberry}

Untuk merancang kemasan Blueberry ini ada beberapa tahapan yang perlu diperhatikan, agar kemasan itu benar-benar sesuai apa yang diharapkan. Tahapan-tahapan itu, yaitu:

1. Menentukan Tujuan Pemosisian Merek.

Didalam mendesain sebuah kemasan Blueberry, yang menjadi masalah utama dalam mendesain kemasan Blueberry adalah bagaimana menciptakan daya tarik kemasan yang tepat dan sesuai dengan target market dari fruit gum Blueberry. Hal ini diungkapkan oleh Imam, Manajer Creative and Design yang di wawancarai.

"Masalah utamanya adalah bagaimana kita menciptakan daya tarik kemasan atau packaging yang menjual yang tepat sesuai dengan target marketnya. Mungkin dari sini bisa juga kita harus nanti ada sedikit survei mungkin kecilkecilan... Bagaimana produk Blueberry itu cocok ga untuk target market, pasar mana? dan sebagainya"

2. Melakukan Analisis Kategori Produk.

Kemasan fruit gum Blueberry ini mempunyai target market yaitu wanita yang dewasa umur 19 sampai 25 tahun. Seperti yang ditunjukan oleh teks hasil wawancara selanjutnya ini.

"Untuk fruit gum Blueberry target marketnya adalah adult kemudian 19 sampai

25 Tahun. Ee...tapi primary targetnya adalah wanita ya...wanita yang adult."

Pernyataan diatas menunjukkan bahwa, untuk mencari gambaran keadaan pasar yang sebenarnya untuk menjamin kemasan Blueberry yang ditujukan pada pasar yang tepat sesuai sasaran yang dituju, misalnya sasaran kelompok umur, jenis kelamin, pendidikan, kelas ekonomi, geografis dan mempelajari prinsip psikologis dan fisiologis kemasan Blueberry agar berdaya tarik bagi calon konsumen.

3. Melakukan Analisis Kompetitif.

Dalam melakukan analisis kompetitif ini, LOTTE sebagai produsen fruit gum Blueberry melakukan evaluasi terhadap produk kompetitor. Hasil dari analisa produk kompetitor tersebut dievaluasi dan akan dilihat apa kelebihan dari produk kompetitor dan apa kekurangan dari produk tersebut. Dari hasil analisa inilah LOTTE selaku produsen dari fruit gum Blueberry ini akan mengambil suatu kesimpulan yang dapat dijadikan referensi dan tolak ukur dalam mendesain kemasan fruit gum Blueberry ini. Mempelajari kegiatan para pesaing dan sifat kemasannya, baik keunggulan atau kekurangan mereka. Kemasan Blueberry harus berbeda dan lebih baik daripada kemasan pesaing. Tujuannya adalah untuk mengangkat citra atau image yang diinginkan oleh konsumen dan juga cukup unik hingga mampu menangkap perhatian calon konsumen. Seperti yang ditunjukkan oleh teks hasil wawancara dengan Angel, Brand Supervisor berikut ini:"Jadi kita menggunakan warna-warna yang jarang dilihat atau jarang dipakai untuk produk chewing gum, kaya blueberry ini kan jarang ditemuinya. Kalau untuk kompetitor pakenya warna kuning, merah dan lain sebagainya. Dan memang Blueberry ini warnanya beda. Kemudian untuk dari segi desainnya kita menonjolkan ke sophisticated produk kita gitu lo..Biar terkesan sangat eksklusif dibandingkan dengan produk lainnya. Kemudian karena kita pengin mengkomunikasikan kejusian buah tersebut, Makanya kita pun membuat desain yang bisa menampilkan kesegaran buah." 
4. Mengidentifikasikan Atribut/Manfaat Merek yang Menonjol.

Bahwa unique Selling Proposition (USP) dari Blueberry harus diangkat oleh kemasan. Hal ini diungkapkan oleh Angel, Brand Supervisor berikut ini: "Blueberry itu kan sebenarnya bagian dari salah satu brand kita yaitu LOTTE Fruit Gum. Tapi kali ini kita fokus ke Blueberry karena Blueberry itu tidak hanya dimiliki oleh LOTTE Indonesia saja, tapi LOTTE -LOTTE yang lain pun punya brand Blueberry ini. Tapi secara keseluruhan sebenarnya komunikasinya adalah Brandnya adalah LOTTE fruit gum. Jadi untuk Uniqe Selling Pointnya pun sama dengan fruit gum yang lainnya yaitu...ee...apa ya...rasanya yang benar-benar seperti rasa buah asli dan juga sangat juicy. Jadi kalau misalnya dilihat.. .kalau misalnya kita ngerasain itu rasanya memang benar-benar seperti rasa Blueberry asli dan kita menonjolkan ke juici-an dari buah blueberry tersebut ke dalam chewing gum. Makanya kenapa kita menggunakan tagline kita yaitu: Kunyah Rasa Asli Buahnya. Kemudian USP yang lainnya pun dari segi desain, warnanya sangat eye catching."

Hasil wawancara diatas memberikan informasi bahwa USP dari Blueberry ini adalah rasanya yang benar-benar rasa buah asli dengan menonjolkan gambar buah Blueberry yang segar

5. Menentukan Prioritas Komunikasi.

Setelah menyebutkan sebagian besar manfaat Blueberry yang menonjol, proses ini secara sederhana mendorong desainer kemasan untuk menentukan prioritas verbal dan visual bagi kemasan. Dalam menentukan prioritas komunikasi ini merupakan kesimpulan dari tahap satu sampai ke empat untuk dijadikan sebagai landasan komunikasinya dalam mendesain kemasan fruit gum Blueberry.

\section{Prinsip-Prinsip Desain Kemasan Fruit Gum Blueberry}

Keunikan desain kemasan fruit gum Blueberry sangat jelas terlihat pada visualisasi bagian depan (tampak muka) kemasan. Untuk lebih jelasnya, desain kemasan akan ditampilkan menjadi 4 bagian, yaitu: 1) Tampak muka depan, 2) Tampak sisi/samping (kiri dan kanan), 3) tampak belakang 4) Tampak keseluruhan.
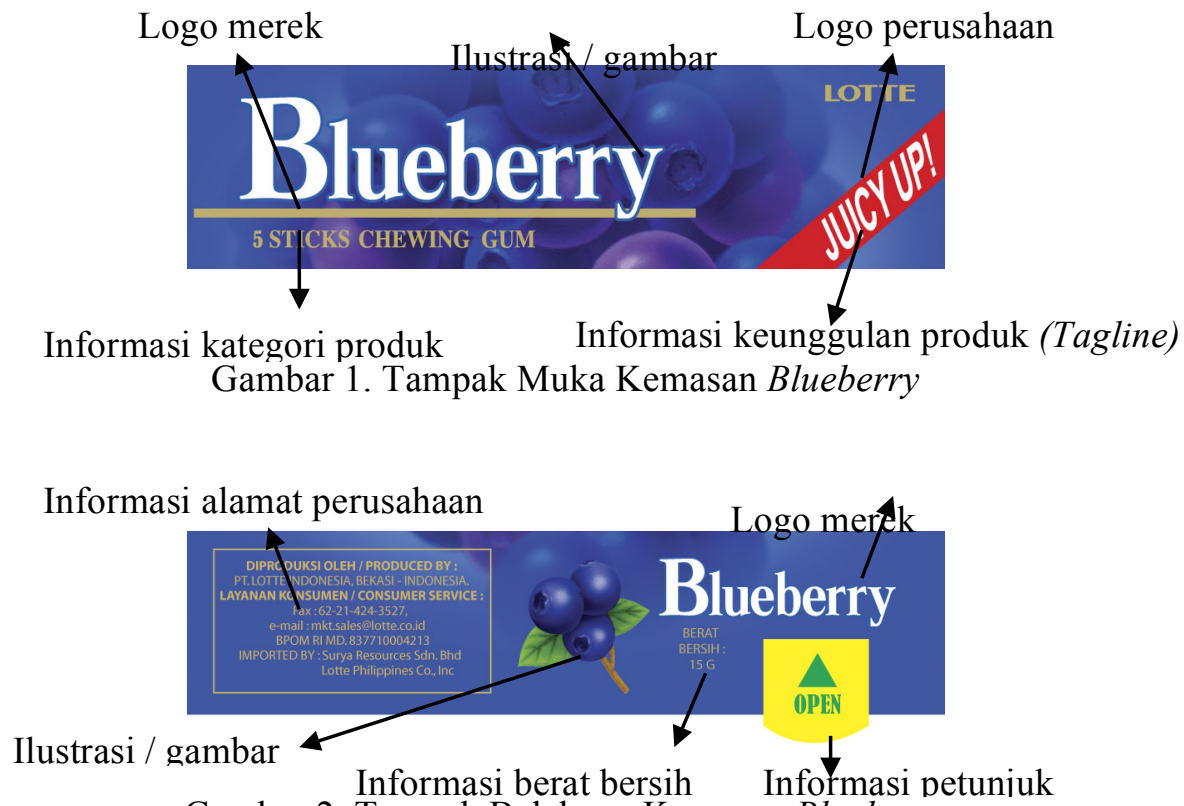

Gambar 2. Tampak Belakang Kemasan Blueberry 


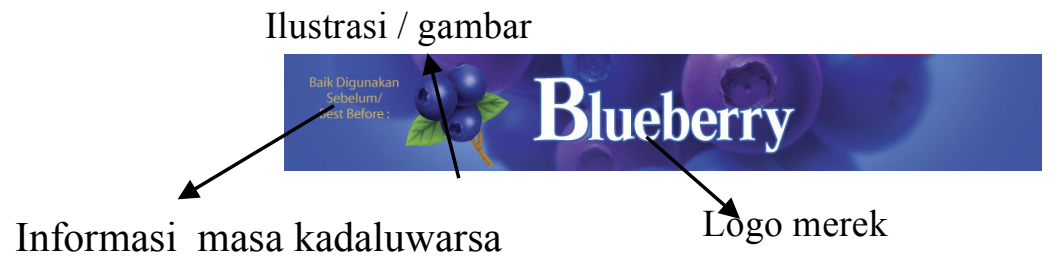

Gambar 3. Tampak Samping Kiri Kemasan Blueberry

Identitas asal produk/kode barang (barcode)

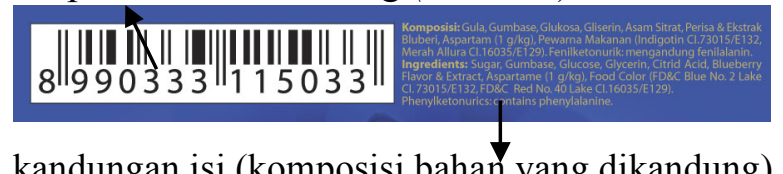

Informasi kandungan isi (komposisi bahañ yang dikandung)

Gambar 4. Tampak Samping Kanan Kemasan Blueberry

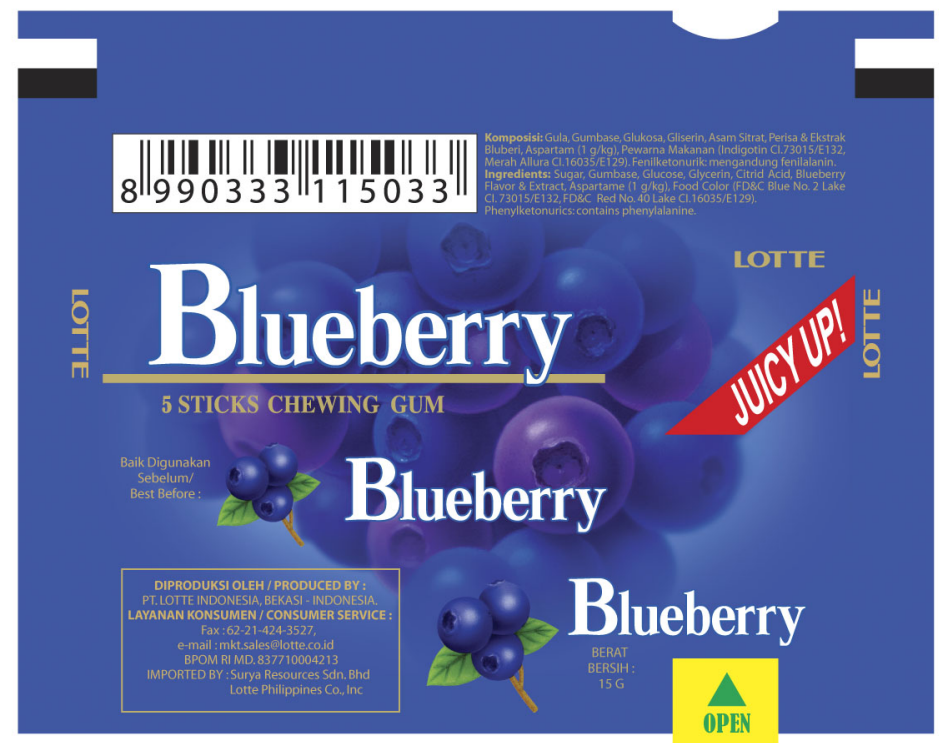

Gambar 5. Tampak Keseluruhan Kemasan Blueberry

\section{Berkomunikasi dengan Warna}

Konsumen melihat warna jauh lebih cepat daripada melihat bentuk atau rupa dan warnalah yang pertama kali terlihat bila produk berada di tempat penjualan. Tapi selain unsur keterlihatan harus dipertimbangkan pula faktor kekontrasan terhadap warna-warna pendukung lainnya. Seperti yang ditunjukkan oleh teks hasil wawancara selanjutnya ini:

"Mungkin kalau bisa saya jawab, hanya dua yang bisa menjadi tolak ukur. Yang pertama adalah warna, yang kedua ilustrasi dari produk itu sendiri. Karena warna sangat penting misalnya anda membeli produk di supermarket. Dari jarak pandang tertentu anda akan melihat bahwa pacakging itu yang paling menarik itu yang paling eye catching dan biasanya eye catching itu dari warna atau mungkin produk yang punya spesifikasi atau bentuk berbeda dari yang lain itu bisa juga orang tertarik." 
Dalam hal kemasan fruit gum Bluebery warna yang digunakan secara keseluruhan dimaksudkan untuk mengidentifikasi merek produk dan untuk dapat membedakan variasi ragam produk fruit gum LOTTE yang lain.

\section{Tipografi}

Teks pada produk media merupakan pesan kata-kata, digunakan untuk menjelaskan produk yang ditawarkan dan sekaligus mengarahkan sedemikian rupa agar konsumen bersikap dan bertindak sesuai dengan harapan LOTTE sebagai produsen fruit gum Blueberry.

Tipe huruf harus disesuaikan dengan tema dan tujuan dari produk itu sendiri. Maka disinilah diperlukan kejelian dalam memilih huruf atau font yang sesuai atau menjiwai dari kemasan Blueberry. Alasan pemilihan tipografi untuk kemasan Blueberry ini mempunyai unsur-unsur yang terdapat dalam kemasan Blueberry. Yaitu memberikan alasan elastisitas dan produk Blueberry ini mempunyai kelas. Hal ini diungkapkan oleh Yusuf, bagian Packaging design berikut ini:

"Ok saya jawab... alasan pemilihan tipografi ya... Pastinya kita sudah melalui konsep memilih tipografi... mengapa kita memilih tipografi ini... pemilihan tipografi ini mempunyai unsur-unsur yang ada pada produk kita...Kenapa? Ee... tipografi ini... memberikan alasan seperti elastisitas dan kelas. Yang tentunya kita tekankan bahwa produk kita memang mempunyai kelas."

Logo merek fruit gum Blueberry, adalah sebuah tulisan yang berwarna putih dengan garis tepi berwarna biru. Merek Blueberry itu menggambarkan ciri khas yaitu mudah untuk dijelaskan, menggugah, mengandung keaslian dan tidak mirip dengan logo-logo produk lain. Setelah mencoba melakukan eksplorasi lebih lanjut, peneliti tidak menemukan jenis tipografi baku yang menjadi tipografi yang membentuk blueberry, karena desainer kemasan secara eksklusif mencoba mendesain khusus tipografi yang digunakan. Namun secara kelompok besarnya, tipografi yang digunakan oleh fruit gum Blueberry dalam logonya, adalah jenis tipografi serif. Dan kelompok tipografi dalam jenis ini, mempunyai asosiasi keindahan, dalam mengkomunikasikan salah satu unsur positioning fruit gum Blueberry yaitu menciptakan gaya hidup yang memiliki estetika, seperti diungkapkan oleh bagian packaging design berikut ini:

"Ok... kita lihat disini ada dua logo ya... Blueberry dan LOTTE. Pada dasarnya Brand utama kita adalah LOTTE. Pada awal-awalnya Blueberry Fruit gum itu dibuat mungkin hampir sama besarnya dengan logo LOTTE itu sendiri tapi berjalan seiring waktu LOTTE mempunyai varian-varian produk banyak sekali... Hingga mungkin itu akan membingungkan konsumen. Tapi kita coba memperbesar logo Blueberry agar bisa berbeda dengan produk-produk LOTTE lainnya."

\section{Struktur Kemasan}

Bentuk kemasan kotak/empat persegi panjang, merupakan pendukung utama yang membantu terciptanya seluruh daya tarik visual. Bentuk kemasan bagi target market fruit gum Blueberry adalah yang paling penting penggunaannya, kemasan fruit gum Blueberry tidak hanya mempunyai nilai fungsional, juga mempunyai nilai emosional dan bahkan nilai estetika. Proses pemilihan bentuk kemasan yang kotak empat persegi panjang seperti kemasan Blueberry ini mempunyai alasan berbagai pertimbangan agar kemasan fruit gum 
Blueberry ini mudah dibawa, dipegang, dibuka dan mudah disimpan. Hal ini diungkapkan oleh informan berikut ini:

"Ya... Kenapa ya...ya agar mudah dibawa... simpel... tidak memakan banyak ruang itu pastinya... Sebenarnya sih... Blueberry produk lotte dari jepang itu mempunyai kapasitas hingga sembilan... hingga sembilan isi.... Tapi dikita hanya lima, tapi itu tidak mempengaruhi dalam konsep dan mengapa kita memilih konsep seperti ini... sekali lagi simpel dan mudah dibawa."

Material kemasan fruit gum Blueberry menggunakan alumunium foil sebagai material kemasannya. Beberapa alasan memilih alumunium foil sebagai material kemasan, seperti dikatakan oleh Manajer Creative and Design sebagai berikut:

"Kalau saya lihat dari alumunium foil, saya coba buka bahwa sebenarnya alumunium foil itu lebuih banyak untuk melindungi produk itu sendiri karena kebetulan juga produk yang lotte bikin Fruit gum Blueberry ini, kita mempunyai komponen salah satunya adalah Acid yaitu asam ya....jangan sampai ketika produk ini dijual permen karet itu lengket. Jadi supaya tidak lengket kita perlu lapisan lain untuk melindungi satu dari asem itu sendiri trus kedua dari sinar matahari panas karena disinar matahari panas lama-lama produk akan meleleh dan lengket. Jadi gunanya alumunium foil untuk melindungi produk yang pertama. Kalau yang kedua ketika alumunium foil dicampur dengan material lain itu ada faktor lain membuat kemasan sedikit lebih mengkilap, dibandingkan kalau kita pake plastik."

Hasil wawancara diatas juga menunjukkan bahwa penggunaan alumunium foil akan menghasilkan desain kemasan yang lebih bagus dibandingkan plastik. Dengan alasan penyerapan tintanya lebih solid.

\section{Berkomunikasi dengan Citra}

Pembubuhan ilustrasi berupa buah Blueberry dalam kemasan ini didasarkan pada fungsinya yaitu ingin mengkomunikasikan bahwa rasanya adalah buah blueberry. Dalam segi grafisnya ditampilkan gambar buah blueberry dengan kondisi matang dan segar. Apabila tidak maka akan menimbulkan kesan asem dalam persepsi kemasan itu. Tentu saja akan mengurangi minat konsumen untuk membeli produk tersebut. Sebagaimana ditunjukkan oleh teks hasil wawancara berikut ini:

"Trus faktor yang kedua dari ilustrasi, dari ilustrasi sendiri itu orang akan senang kalau melihat ilustrasi itu dalam arti jangan sampai misalkan kita mau bikin bentuk A tapi hasilnya jadi B.

Saya pikir faktor dua ini profesional, kita harus bikin benar-benar tepat. Kaya misalkan produk blueberry yang kita bikin misalkan ini...kita bikin blueberry ini untuk katagori ini...kita bikin buahnya yang harus kita tonjolkan benar-benar buah blueberry dari segi grafisnya dia harus terlihat elegan, jangan sampai buah ini kelihatan buahnya masih kelihatan agak mentah, buahnya kelihatan kurang bagus. Faktor ilustrasi sangat penting menurut saya." 


\section{KESIMPULAN}

Setelah melakukan kajian deskriptif terhadap kemasan Blueberry, dihubungkan dengan strategi isi pesan kemasan Blueberry didalam mengomunikasikan positioning merek (brand positioning)-nya, maka sebagai akhir dari penelitian ini, akan dipaparkan kesimpulan-kesimpulan sabagai berikut:

Dalam dunia pemasaran, PT. LOTTE INDONESIA, sebagai produsen melakukan proses komunikasi pemasaran dalam rangka mengomunikasikan Blueberry, produknya kepada pasar sasaran. Salah satu medium komunikasi terpenting yang dimiliki oleh Blueberry sebagai produk adalah kemasan. Selain itu kemasan juga sebagai medium yang mengiklankan diri produk itu sendiri atau sebagai duta bagi produk itu sendiri secara terus menerus, baik itu ditempat penjualan maupun pada saat penggunaannya.

Positioning yang dimiliki Blueberry adalah memposisikan wanita yang dewasa, aktif, stylish dan modern. Dari positioning yang ada tersebut dapat dijabarkan bahwa Blueberry adalah produk yang memiliki value, yaitu Functional Value yaitu bahwa fruit gum Blueberry adalah produk chewing gum yang mempunyai kandungan rasa buah asli yang segar dan baik untuk kesehatan kemudian Emotional Value yaitu bahwa Blueberry adalah produk chewing gum yang menawarkan keeksklusifan dan sophisticated desain yang tidak dimiliki langsung oleh kompetitor dan Esthetic Value yaitu bahwa Blueberry menawarkan suatu nilai gaya hidup tersendiri yang aktif, stylish dan modern yang sangat memperhatikan estetika. Menjadi nilai tambah bagi calon konsumen di dalam merasakan benefit yang dimiliki oleh fruit gum Blueberry. Dan penjabaran positioning merek tersebutlah yang dikomunikasikan oleh Blueberry melalui prinsip desain kemasan yaitu berkaitan dengan warna, tipografi struktur kemasan dan Citra.

Kata estetika, sebagai inti dari positioning fruit gum Blueberry, dikomunikasikan oleh kemasan produk melalui warna, tipografi struktur kemasan dan Citra. kepada khalayak sasarannya. Sehinggga menciptakan value-value yang akhirnya memperkuat posisi merek fruit gum Blueberry sebagai fruit gum yang mempunyai cita rasa dan berestetika.

Disimpulkan bahwa komunikasi yang disampaikan oleh suatu kemasan tidak hanya berasal dari satu komponen saja, tetapi disampaikan dalam satu kesatuan dengan komponen lainnya.

\section{SARAN}

Langkah-langkah yang diambil PT. LOTTE INDONESIA didalam merancang dan merencanakan kemasan produknya, yaitu Blueberry telah mengikuti proses perencanaan perancangan kemasan dengan sistematis. Karena seperti diketahui, kemasan Blueberry sangat memperhatikan setiap detil elemennya sebagai medium komunikasi bagi produknya, khususnya didalam mengomunikasikan brand positioning.

Khususnya untuk menghadapi munculnya kompetitor-kompetitor baru yang menggunakan positioning sama dengan Blueberry. Dimana mengharuskan Blueberry melakukan proses re-design pada kemasannya. Maka harus ada suatu langkah antisipasi, yaitu dengan mempersiapkan rencana program kegiatan promosi dan periklanan yang baik, yaitu tetap konsisten dalam mengomunikasikan positioning-nya yang memposisikan wanita yang dewasa, aktif, stylish dan modern. Sehingga dapat menjaga kekuatan merek Blueberry yang dapat fleksibel mengomunikasikan positioning yang dimilikinya. Sehingga apabila muncul kompetitor-kompetitor baru yang mempunyai produk sama dengan Blueberry, maka PT. LOTTE INDONESIA tidak harus mengganti, merancang ulang dan memproduksi suatu kemasan baru bagi Blueberry yang akan mengakibatkan terjadinya pengeluaran yang cukup besar bagi PT. LOTTE INDONESIA sebagai produsen fruit gum Blueberry. 


\section{DAFTAR PUSTAKA}

AMR, 2001, "Gerilya Promosi Lewat Kemasan”, Cakram Komunikasi, Jakarta.

Bungin, Burhan, 2003, "Metode Penelitian Kualitatif", PT. Raja Grafindo Persada, Jakarta.

Khasali, Rhenald, 1998, "Membidik Pasar Indonesia; Segmenting, Targeting dan Positioning", PT. Gramedia Pustaka Utama, Jakarta.

Klimchuk, Marianne Rosner \& Krasovec, Sandra A, 2007, "Desain Kemasan: Perencanaan Merek Produk yang Berhasil Mulai dari Konsep sampai Penjualan”, Jakarta: Erlangga

Moleong, Lexy J. 1999, "Metode Penelitian Kualitatif", PT. Remaja Rosdakarya, Bandung.

Rakhmat, Jalaluddin, 2005, "Psikologi Komunikasi, PT. Remaja Rosdakarya, Bandung. , 1998, "Metode Penelitian Komunikasi", Cetakan Keenam, PT. Remaja Rosdakarya, Bandung.

Rangkuti, Freddy, 2002, "The Power of Brands", PT. Gramedia Pustaka Utama, Jakarta.

Shimp, Terence A, 2003, "Periklanan dan Promosi", Erlangga, Jakarta.

Simamora, Bilson. 2003, “Aura Merek”, PT. Gramedia Pustaka Utama, Jakarta.

Sihombing, Danton. 2001, "Tipografi Dalam Desain Grafis", PT. Gramedia Pustaka Utama, Jakarta.

Sushan, Ronnie \& Don, Wright. 1991, “Desktop Publishing Dalam Desain”, PT. Elek Media Komputindo, Jakarta.

Sugiyono, 2005, “Memahami Penelitian Kualitatif”, CV. Alfabeta, Bandung.

Suyanto, M. 2004, "Desain Grafis Dalam Periklanan", CV. Andi, Yogyakarta.

Tjiptono, Fandy, 1997, "Strategi Pemasaran", CV. Andi, Yogyakarta 